\title{
Fetuin-A: A negative acute-phase protein linked to adipose tissue function in periparturient dairy cows
}

\author{
Clarissa Strieder-Barboza, ${ }^{*}$ Jonas de Souza, $\dagger$ William Raphael, ${ }^{*}$ Adam L. Lock, $\dagger$ and G. Andres Contreras* \\ *Department of Large Animal Clinical Sciences, College of Veterinary Medicine, and \\ †Department of Animal Science, Michigan State University, East Lansing 48824
}

\begin{abstract}
Fetuin-A (FetA) is a free fatty acid transporter and an acute-phase protein that enhances cellular lipid uptake and lipogenesis. In nonruminants, FetA is involved in lipid-induced inflammation. Despite FetA importance in lipid metabolism and inflammation, its expression and dynamics in adipose tissue (AT) of dairy cows are unknown. The objectives of this study were to (1) determine serum and AT FetA dynamics over the periparturient period and in mid-lactation cows in negative energy balance (NEB) after a feed restriction protocol and (2) characterize how an inflammatory challenge affects adipocyte FetA expression. Blood and subcutaneous AT were collected from 16 cows with high $(\geq 3.75$, $\mathrm{n}=8)$ or moderate $(\leq 3.5, \mathrm{n}=8)$ body condition score (BCS) at $-26 \pm 7 \mathrm{~d}$ (far off) and $-8 \pm 5 \mathrm{~d}$ (close up) before calving and at $10 \pm 2 \mathrm{~d}$ after parturition (early lactation) and from 14 nonpregnant mid-lactation cows $(>220 \mathrm{~d}$ in milk) after a feed restriction protocol. Serum FetA concentrations were $0.89 \pm 0.13 \mathrm{mg} / \mathrm{mL}$ at far off, $0.96 \pm 0.13 \mathrm{mg} / \mathrm{mL}$ at close up, and $0.77 \pm 0.13$ $\mathrm{mg} / \mathrm{mL}$ at early lactation and were $1.09 \pm 0.09$ and $1.17 \pm 0.09 \mathrm{mg} / \mathrm{mL}$ in feed-restricted and control cows, respectively. Serum and AT FetA contents decreased at the onset of lactation when lipolysis was higher. No changes in AT and serum FetA were observed after feed restriction induced NEB in mid-lactation cows. Prepartum BCS had no effect on serum FetA, but AT expression of $A H S G$, the gene encoding FetA, was reduced in periparturient cows with high BCS at dryoff throughout all time points. Circulating FetA was positively associated with serum albumin and calcium and with BCS variation over the periparturient period. The dynamics of $A H S G$ expression were analogous to the patterns of lipogenic markers ABDH5, ELOVL6, $F A B P 4, F A S N, P P A R \gamma$, and SCD1. Expression of $A H S G$ and FetA protein in AT was inversely correlated
\end{abstract}

Received August 8, 2017.

Accepted November 2, 2017.

${ }^{1}$ Corresponding author: contre28@msu.edu with AT proinflammatory markers $C D 68, C D 44, S P P 1$, and CCL2. In vitro, bovine adipocytes challenged with lipopolysaccharide downregulated FetA protein expression. Adipocytes treated with FetA had lower CCL2 expression compared with those exposed to lipopolysaccharide. Overall, FetA is a systemic and local AT negative acute-phase protein linked to AT function in periparturient cows. Furthermore, FetA may support physiological adaptations to NEB in periparturient cows.

Key words: adipose tissue, biomarker, inflammation, lipolysis, transition cow

\section{INTRODUCTION}

Periparturient dairy cows enter a state of negative energy balance (NEB) driven by the onset of lactation and reduced feed intake, which in turn enhances adipose tissue (AT) lipolysis and the release of free fatty acids (FFA) into systemic circulation. As lactation progresses, lipolysis rate decreases and lipogenesis replenishes triacylglycerol stores in adipocytes. This process requires the enhancement of fatty acid (FA) uptake and transport within AT. Fetuin-A (FetA; formerly named $\alpha$-2-Heremans-Schmid glycoprotein) is a $64-\mathrm{kDa}$ liver-derived circulating glycoprotein that functions as a major carrier of FFA in plasma (Subbiah, 1991; Heinrichsdorff and Olefsky, 2012) and promotes lipogenesis in different cell types (Kumbla et al., 1989; Zaitsu and Serrero, 1990). In a human adipogenic model, FetA increased the incorporation of exogenous FA into intracellular lipids and increased cellular triacylglycerol synthesis compared with albumin, the best-characterized FA transporter (Cayatte et al., 1990). Besides being synthesized by liver, secretion of functional FetA was demonstrated in human and murine white AT (Jialal et al., 2016; Pérez-Sotelo et al., 2017). Adipose tissue-derived FetA increases in human patients with metabolic syndrome and obesity (Jialal et al., 2015; Pérez-Sotelo et al., 2017) and in animals fed a high-fat diet (Pérez-Sotelo et al., 2017). Due to its lipogenic properties, FetA is positively associated 
with visceral fat mass accumulation, hepatocyte lipid infiltration, and increased circulating FFA and triacylglycerol in humans (Chen et al., 2009; Ix and Sharma, 2010; Pérez-Sotelo et al., 2017). These findings suggest that FetA may participate in FFA transport and cellular uptake and in triacylglycerol re-esterification during NEB in dairy cows; however, changes in the expression of FetA in dairy cows during periods of intense lipid mobilization have not yet been explored.

Fetuin-A appears to play different roles during acute and chronic inflammatory responses. During acute inflammation, FetA is characterized as a negative acute-phase protein (APP) and has anti-inflammatory properties in various acute conditions such as sepsis, endotoxemia, trauma, and cerebral ischemic injury ( $\mathrm{Li}$ et al., 2011; Wang and Sama, 2012). These properties are related to the fact that FetA inhibits tumor necrosis factor $\alpha$ (TNF) production by immune cells during acute inflammation (Wang and Sama, 2012). However, FetA is downregulated by proinflammatory cytokines such as TNF, IL-6, IL-1, and IFN- $\gamma$ (Daveau et al., 1988; Li et al., 2011). In contrast, during chronic inflammation, FetA appears to upregulate proinflammatory responses and impair the response to insulin in cells of AT, liver, and skeletal muscle (Stefan et al., 2008; Dasgupta et al., 2010). In fact, FetA was identified as an endogenous ligand between FFA and toll-like receptor-4 in adipocytes that triggers lipid-induced inflammation, resulting in insulin resistance in AT (Heinrichsdorff and Olefsky, 2012; Pal et al., 2012). Consequently, FetA concentrations in plasma and AT $A H S G$ expression, the gene encoding FetA, were upregulated during chronic inflammation in obese humans and rodents with increased plasma FFA concentrations (Heinrichsdorff and Olefsky, 2012; Jialal et al., 2015; Pérez-Sotelo et al., 2017). Although periparturient dairy cows have increased FFA concentrations, which lead to systemic and local AT inflammation (Saremi et al., 2014; Mann et al., 2016), the potential effects of inflammatory responses induced by exacerbated lipolysis on circulating and AT FetA around parturition and through early lactation in dairy cows remain unknown. The objectives of the present study were (1) to determine the dynamics of serum and AT FetA during the periparturient period and in nonpregnant mid-lactation cows during feed restriction-induced NEB and (2) to investigate how inflammation affects FetA expression in bovine adipocytes.

\section{MATERIALS AND METHODS}

All animal procedures were approved by the Michigan State University Animal Care and Use Committee.

\section{Animals, Diet, and Experimental Design}

Experiment 1. Sixteen clinically healthy multiparous (2.8 \pm 0.9 lactations) Holstein dairy cows from the Michigan State University Dairy Teaching and Research Center (East Lansing, MI) were enrolled in this study. At the moment of selection, cows were nonlactating and pregnant ( $\geq 235 \mathrm{~d}$ of gestation). Cows were housed in tiestall barns bedded with sawdust and fed a dryperiod TMR diet from 60 to $21 \mathrm{~d}$ prepartum, a close-up diet from $21 \mathrm{~d}$ up to calving, and an early-lactation diet following parturition (Table 1). Cows were assigned to 1 of 2 groups according to their BCS (1-to- 5 scale; Edmonson et al., 1989) at dry-off: high BCS (HBCS; $\mathrm{BCS} \geq 3.75 ; \mathrm{n}=8$ ) or moderate BCS (MBCS; BCS $\geq$ $2.75 \leq 3.5 ; \mathrm{n}=8$ ). The average BCS at dry-off was 3.94 \pm 0.13 for HBCS and $3.32 \pm 0.13$ for MBCS. Body condition score was evaluated before blood and AT sample collections by 3 experienced technicians and averaged for statistical analysis. Blood samples and subcutaneous AT were obtained at 3 different time points relative to calving date (mean days $\pm \mathrm{SD}$ ): far-off dry (FO; $-26 \pm 7 \mathrm{~d}$ ), close-up dry (CU; $-8 \pm 5 \mathrm{~d})$, and early lactation (EL; $10 \pm 2 \mathrm{~d}$ ).

Experiment 2. Fourteen mid-lactation (223 DIM \pm 103) nonpregnant Holstein dairy cows from the Michigan State University Dairy Teaching and Research Center were randomly assigned to 1 of 2 feeding protocols: feed restricted $(\mathbf{F R} ; \mathrm{n}=7)$ or ad libitum $(\mathbf{A L} ; \mathrm{n}$ $=7$ ). Animals were fed a common diet formulated to meet nutrient requirements during a 14-d preliminary period relative to the beginning of treatment protocols and then were randomly assigned to treatment. Feed intake was reduced in FR cows for $4 \mathrm{~d}$ to achieve a target NEB of $-15 \mathrm{Mcal} / \mathrm{d}$, similar to the degree of NEB typically observed during the periparturient period. All cows received a common TMR formulated to meet or exceed nutrient requirements. Blood samples for FetA analysis were obtained on $\mathrm{d}-2$ and 4 relative to the

Table 1. Nutrient composition of diets fed during the far-off (60 to 21 d prepartum), close-up (21 d prepartum up to calving), and earlylactation (after parturition) periods to 16 multiparous Holstein dairy cows in experiment 1

\begin{tabular}{lccc}
\hline $\begin{array}{l}\text { Ingredient, \% of DM } \\
\text { unless noted }\end{array}$ & Far off & Close up & $\begin{array}{c}\text { Early } \\
\text { lactation }\end{array}$ \\
\hline $\mathrm{DM}$ & 62.1 & 56.3 & 51.2 \\
$\mathrm{NDF}$ & 52.1 & 44.3 & 30.5 \\
$\mathrm{CP}$ & 11.7 & 13.8 & 17.7 \\
Starch & 16.4 & 18.5 & 24.0 \\
$\mathrm{Ca}$ & 0.62 & 0.84 & 1.08 \\
$\mathrm{P}$ & 0.26 & 0.30 & 0.55 \\
Fatty acids & 1.67 & 1.80 & 2.50 \\
$\mathrm{NE}_{\mathrm{L}}, \mathrm{Mcal} / \mathrm{d}$ & 1.35 & 1.45 & 1.68 \\
\hline
\end{tabular}


onset of feeding protocols. Omental and subcutaneous AT samples were collected on d 4 of the experimental period using minimally invasive surgical techniques in vivo or postmortem. Procedures for this experiment are described in detail in Contreras et al. (2016b).

\section{Blood Collection and Analysis}

Blood samples were collected via coccygeal venipuncture using EDTA-treated and uncoated serum collection tubes, centrifuged at $3,000 \times g$ for $20 \mathrm{~min}$ at $15^{\circ} \mathrm{C}$ for plasma and serum fractions collection, and then stored at $-80^{\circ} \mathrm{C}$ until further analysis. Serum concentrations of FFA, BHB, total cholesterol, glucose, albumin, and calcium were determined using an Olympus AU640e chemistry analyzer (Olympus America, Center Valley, PA) at the Diagnostic Center for Population and Animal Health of Michigan State University. Serum insulin concentrations were determined by ELISA (bovine insulin ELISA; Mercodia AB, Uppsala, Sweden) with intra- and interassay coefficients of variation of 4.50 and $4.35 \%$, respectively. Serum FetA concentrations were determined by ELISA following the manufacturer's guidelines (cow AHSG/fetuin A, cat. no. LS-F6106; LSBio, Seattle, WA) using a Synergy H1 microplate reader (Biotek, Vermont, MA). Intra- and interassay coefficients of variation for FetA ELISA were 4.45 and $4.50 \%$, respectively.

\section{AT Collection and Processing}

Adipose tissue samples were collected using minimally invasive surgical techniques as previously described (Contreras et al., 2015, 2016b). Briefly, in experiment 1 , animals received local anesthesia using $2 \%$ lidocaine hydrochloride (Aspen Veterinary Resources, Greely, $\mathrm{CO}$ ), and a $4-\mathrm{cm} \mathrm{V}$ incision was made through the skin at the tailhead 5 to $10 \mathrm{~cm}$ laterally from the medial line and 5 to $10 \mathrm{~cm}$ cranial to the base of the tail. A total of 3 to $5 \mathrm{~g}$ of subcutaneous AT was obtained from the surgical site. The incision was closed with synthetic nonabsorbable sutures in a buried suture pattern. Subsequent biopsies were obtained from a site opposite to the previous incision. In experiment 2,3 to $5 \mathrm{~g}$ of omental and subcutaneous AT was collected through the right paralumbar fossa by minimally invasive laparoscopy technique or postmortem (Contreras et al., 2016b). Immediately after harvesting, samples for protein analysis were snap frozen and stored at $-80^{\circ} \mathrm{C}$. For gene expression analysis, samples were collected in RNA Later (Life Technologies, Carlsbad, CA), snap frozen, and stored at $-80^{\circ} \mathrm{C}$.

\section{Adipocyte Culture}

Stromal vascular fraction cells were obtained by collagenase digestion of tailhead subcutaneous AT collected from nonlactating nongestating dairy cows $(\mathrm{n}=$ 6 ) at a local abattoir as described previously (Contreras et al., 2015). Stromal vascular fraction cells were cultured in basal medium containing Dulbecco's modified Eagle's medium: F12 (Corning, Corning, NY), 10\% fetal bovine serum (Corning), $2 \mathrm{mmol} / \mathrm{L}$ of L-glutamine (Corning), 1\% (vol/vol) antibiotic-antimycotic (Corning), $44.05 \mathrm{mmol} / \mathrm{L}$ of sodium bicarbonate (SigmaAldrich, St. Louis, MO), $100 \mu \mathrm{mol} / \mathrm{L}$ of ascorbic acid (Sigma-Aldrich), $33 \mu \mathrm{mol} / \mathrm{L}$ of biotin (Sigma-Aldrich), $17 \mu \mathrm{mol} / \mathrm{L}$ of pantothenate (Sigma-Aldrich), and 20 mmol/L of HEPES (Corning) with replacement every $2 \mathrm{~d}$ as described previously (Contreras et al., 2016a). Preadipocytes were obtained by outgrowth of plastic adherent cells from the stromal vascular fraction cells after 2 serial passages. Preadipocytes were induced to differentiate after $48 \mathrm{~h}$ at $100 \%$ confluency (d 0) using a basal medium formulation supplemented with $10 \%$ fetal bovine serum, $5 \mu \mathrm{mol} / \mathrm{L}$ of troglitazone (Cayman Chemical, Ann Arbor, MI), and the following reagents from Sigma-Aldrich: $5 \mu \mathrm{g} / \mathrm{mL}$ of insulin, $0.5 \mathrm{mmol} / \mathrm{L}$ of 2 isobutyl-1-methylaxanthine (IBMX), and $1 \mu \mathrm{mol} / \mathrm{L}$ of dexamethasone. Thereafter, cells were maintained in medium without IBMX and dexamethasone for $10 \mathrm{~d}$, with medium changes every $48 \mathrm{~h}$. From d 0 to 10 of differentiation, basal medium was supplemented with 100 $\mu \mathrm{mol} / \mathrm{L}$ of an FA mixture mimicking the FA profile of the plasma FFA fraction during the first week of lactation (Contreras et al., 2012). The FA mixture included myristic acid (C14:0; 3\%), palmitic acid (C16:0; 30\%), stearic acid (C18:0; 45\%), and oleic (C18:1n-9 cis; $16 \%$ ), linoleic (C18:2n-6 cis; 5\%), and docosahexaenoic FA (C22:6n-3 cis; 1\%; Contreras et al., 2010, 2012). After $10 \mathrm{~d}$ of differentiation, lipid accumulation was assessed quantitatively in triplicate per experimental unit using the AdipoRed assay (Lonza, Allendale, NJ) on adipocytes cultured in 96-well plates $(\mathrm{n}=6)$ using a Synergy H1 microplate reader (Biotek). Lipid accumulation was evaluated qualitatively with Oil Red O staining using 12-well plates, with imaging performed on a Nikon Eclipse inverted microscope equipped with a Nikon Digital Sight DS Qil camera (Nikon Group, Otowara, Japan).

\section{Adipocyte Inflammatory Challenge}

At d 10 of differentiation, bovine adipocytes were serum starved using basal medium without fetal bovine serum for $16 \mathrm{~h}$ and then washed twice with $1 \times$ PBS 
(Corning). Next, cells were incubated with or without $250 \mathrm{ng} / \mathrm{mL}$ of LPS (cat. no. L4391; Sigma-Aldrich) for $4 \mathrm{~h}$ or with $0,50,100$, or $200 \mu \mathrm{g} / \mathrm{mL}$ of bovine FetA (cat. no. 341506; Millipore, Darmstadt, Germany) for $8 \mathrm{~h}$ at $37^{\circ} \mathrm{C}$ in a humidified atmosphere with $5 \% \mathrm{CO}_{2}$. This experiment was performed in triplicate per each experimental unit $(\mathrm{n}=6)$. The LPS dose was based on a dose-response $(25,100,250$, or $1,000 \mathrm{ng} / \mathrm{mL}$ of LPS $)$ experiment using CCL2 gene expression as the output.

\section{Gene Expression Analysis by Quantitative PCR}

Adipose tissue RNA extraction and quantitative PCR analysis were performed as described previously (Contreras et al., 2014). The RNA of cultured adipocytes was extracted using Promega simplyRNA Cells kits (cat. no. AS1390; Promega, Madison, WI) in the Maxwell RSC instrument (Promega). Briefly, after removing the culture medium and rinsing cells twice with ice-cold $1 \times$ PBS, $200 \mu \mathrm{L}$ of 1-thioglycerol/homogenization solution was added to each well of 6 -well plates with adipocytes and then transferred to a microfuge tube. Next, $200 \mu \mathrm{L}$ of lysis buffer was added, and the homogenate was vortexed and then placed in Maxwell RSC cartridges, which were previously loaded with 10 $\mu \mathrm{L}$ of DNase I. Purity, concentration, and integrity of AT and the cells' RNA were evaluated using an Agilent Bioanalyzer 2100 (Agilent Technologies, Santa Clara, CA) and Caliper Labchip GX system (Caliper Life Sciences, Hopkinton, MA). All samples had an RNA integrity number $\geq 6$. Conversion to $\mathrm{cDNA}$ was performed using the Applied Biosystems High Capacity cDNA Archive kit (Applied Biosystems, Foster City, CA). The quantitative PCR assays were conducted with TaqMan gene expression assays from Applied Biosystems with the exception of FetA $(A H S G)$, which was provided by Integrated DNA Technologies (Coralville, IA; Supplemental Table S1, https://doi.org/10.3168/ jds.2017-13644). Bovine AHSG primer sequences were as follows: forward, GACTTGCGCCACACTTTCTC; reverse, CTGATTCTCCCTGGGCAAAG (Wathes et al., 2011). The TaqMan probe sequence for these primers was designed by Integrated DNA Technologies: TCAGTGGAGTCATCCTCGGGAGAA. The melting temperature for $A H S G$ forward and reverse primers was $62^{\circ} \mathrm{C}$ and $63^{\circ} \mathrm{C}$, respectively, whereas for the probe was it $68^{\circ} \mathrm{C}$, and the assay provided an amplicon size of 137 base pairs. Samples were assayed in triplicate on the Wafergen Smartchip System 205 (WaferGen Biosystems, Fremont, CA). For analysis of AHSG transcription, samples were assayed in a 7500 Fast Real-Time PCR System (Applied Biosystems). Data are presented as fold changes in mRNA expres- sion calculated from least squares means differences according to the formula $2^{-\Delta \Delta \mathrm{Ct}}(\mathrm{CT}=$ cycle threshold $)$, where $\Delta \mathrm{Ct}=\mathrm{Ct}_{\text {target gene }}-\mathrm{Ct}_{\text {control gene }}$ and $\Delta \Delta \mathrm{Ct}=$ $\Delta \mathrm{Ct}_{\text {target sample }}-\Delta \mathrm{Ct}_{\text {calibrator sample. }}$ Control genes were selected as previously described (Steibel et al., 2009) using Data Assist software (Applied Biosystems) and included EIF3K, RPS9, and B2M. For reporting, expression data were normalized to the arithmetic mean of these housekeeping genes. Statistical analysis was performed on the $\Delta \mathrm{Ct}$ values as described previously (Steibel et al., 2009).

\section{Western Blotting}

Western blots were performed as described by Kabara et al. (2014) with some modifications. For protein extraction from cultured adipocytes collection, the medium was discarded and then cells were washed with ice-cold 1× PBS before adding ice-cold RIPA buffer (Teknova, Hollister, CA) containing protease (Roche, San Francisco, CA) and phosphatase (Thermo Scientific, Waltham, MA) inhibitors to each well. Cells were collected using plastic cell scrapers and placed in microfuge tubes, which were then agitated for $1 \mathrm{~h}$ at $4^{\circ} \mathrm{C}$, homogenized in an ultrasonic sonifier (Branson Sonifier S-250, Atkinson, NH; settings: 4-s cycle time, $60 \%$ duty cycle, 4 output control setting), and centrifuged twice at $12,000 \times g$ for $10 \mathrm{~min}$ at $4^{\circ} \mathrm{C}$ to obtain the nonfat layer with protein. For AT, each sample was placed in RIPA buffer and homogenized for 30 to $60 \mathrm{~s}$ using an electric homogenizer (Bio-Gen PRO200, Pro Scientific, Oxford, CT) before being sonicated and centrifuged as described for cultured adipocytes. Estimation of protein content was carried out using the Pierce BCA Protein Assay kit (Thermo Scientific). The FetA content was analyzed using reducing conditions. Briefly, samples were added to a reducing buffer containing $10 \mathrm{mmol} / \mathrm{L}$ of dithiothreitol and 5\% mercaptoethanol and denatured at $95^{\circ} \mathrm{C}$ for $4 \mathrm{~min}$. Equal amounts of total protein (20 $\mu \mathrm{g}$ for AT; $1 \mu \mathrm{g}$ for adipocytes) were electrophoresed on a 4 to $20 \%$ SDS-PAGE gel and transferred to a polyvinylidene difluoride membrane. The membrane was blocked in Tris-buffered saline solution with $0.01 \%$ Tween-20 (TBST) and 5\% BSA. Membranes containing protein from AT samples were incubated with a polyclonal goat anti-human FetA (N-20) antibody (cat. no. sc-9663, RRID:AB_640424; Santa Cruz Biotechnology, Dallas, TX) in a 1:200 dilution in TBST-5\% BSA for $1 \mathrm{~h}$ at room temperature. Membranes containing protein from cultured bovine adipocytes were incubated with rabbit anti-bovine FetA antibody (cat. no. FETB11-S; Alpha Diagnostic, San Antonio, TX) using a 1:1,000 dilution in TBST-5\% BSA for $24 \mathrm{~h}$ at $8^{\circ} \mathrm{C}$. 
Next, membranes were incubated with the correspondent anti-host IgG secondary antibody labeled with horseradish peroxidase 1:10,000 dilution in TBST-5\% BSA (Jackson Immunoresearch, West Grove, PA) for $1 \mathrm{~h}$ at room temperature. Membranes were then exposed to horseradish peroxidase substrate (cat. no. WBLUR0100; Millipore) and visualized by chemiluminescence using the ChemiDoc Touch Imaging System (Bio-Rad, Hercules, CA). Details on band detection corresponding to the expected size of FetA $(64 \mathrm{kDa})$ are described in Supplemental Figure S1 (https://doi.org/ 10.3168/jds.2017-13644). $\alpha \beta$-Tubulin (1:1,000; cat. no. 2148; Cell Signaling Technology, Danvers, MA) and vinculin (1:1,000; cat. no. 4650, RRID:AB_10559207; Cell Signaling Technology) served as loading controls for AT and cultured adipocyte protein, respectively. The protein content of the loading controls was not affected $(P$ $>0.05)$ by period ( $\alpha \beta$-tubulin) or treatment with LPS (vinculin). Band densitometry was determined using Image Lab software (Bio-Rad). Values of FetA protein content are expressed as means of relative band density using loading control values as a calibrator.

\section{Statistical Analysis}

Data were analyzed using the mixed model procedure of SAS (version 9.4; SAS Institute Inc., Cary, $\mathrm{NC}$ ). Results from experiment 1 were analyzed with a general linear mixed model with repeated measures that included the fixed effects of prepartum BCS group, time point, and their interaction and the random effect of cow. Repeated measures over time were modeled with an autoregressive covariance structure, and denominator degrees of freedom were estimated using the Kenward-Roger method. Experiment 2 data were analyzed with a general linear mixed model that included the fixed effects of treatment (AL vs. FR), AT depot sample (subcutaneous vs. omental), and their interaction and the random effect of cow. Correlation analyses for the selected variables were performed with the CORR procedure of SAS. Normality of the residuals was checked with normal probability and box plots, and homogeneity of variances with plots of residuals versus predicted values. Least squares mean differences were determined by $t$-tests using the PDIFF option. Main effects, least squares mean differences, and interaction terms were considered significant when $P \leq 0.05$ and tendencies when $P<0.10$. Real-time quantitative PCR and Western blot results from cell culture experiments were analyzed by 1-way ANOVA followed by Tukey's multiple comparison analysis using JMP Statistical Software (SAS Institute Inc.). Results were considered significant when $P \leq 0.05$.

\section{RESULTS}

\section{Circulating and AT FetA Dynamics in Periparturient Cows}

Using the cohort of cows described in experiment 1 , we determined the circulating concentration of FetA during the periparturient period (Figure 1A). Fetuin-A concentrations were $0.89 \pm 0.13,0.96 \pm 0.13$, and $0.77 \pm$ $0.13 \mathrm{mg} / \mathrm{mL}$ at FO, CU, and EL, respectively. Fetuin-A at EL was lower compared with CU $(P=0.039)$. Serum concentrations of BHB and FFA increased at the onset of lactation, whereas the concentrations of glucose and insulin as well as BCS decreased following parturition (Figure 1B-I). A correlation analysis indicated that circulating FetA concentrations were positively associated with serum concentrations of albumin and calcium and BCS variation throughout the periparturient period (Table 2).

In the same cohort of cows, we evaluated FetA gene expression $(A H S G)$ and protein content in AT. Due to poor RNA yield and quality, FetA analysis in AT was performed only in 10 out of 16 cows $(\mathrm{HBCS}=6$; MBCS $=4)$. The $A H S G$ transcription was lower at $\mathrm{CU}$ and EL compared with FO $(P=0.03)$ but did not differ between CU and EL $(P>0.05$; Figure 2A). Adipose tissue FetA protein expression, as evaluated by Western blot, was also lower at CU and EL compared with FO $(P=0.02)$. However, AT FetA protein expression at $\mathrm{CU}$ was the least (Figure $2 \mathrm{~B}$ ).

\section{FetA and AT Function During the Periparturient Period}

To further characterize AT function in cows from experiment 1, we evaluated the expression of gene networks related to insulin signaling, inflammatory response and immune cell infiltration, extracellular matrix, mitotic activity, and lipid mobilization over the periparturient period (Table 3). Adipose AHSG transcription decreased following parturition concomitantly with a reduced expression of markers of insulin signaling, adipogenesis, lipogenesis, and lipid transport, including ADIPOQ (encoding adiponectin), GLUT4 (encoding glucose transporter-4), ABHD5 (encoding 1-acylglycerol-3-phosphate $O$-acyltransferase), FABP4 (encoding FA binding protein 4), FASN (encoding FA synthase), $P P A R \gamma$ (encoding peroxisome proliferatoractivated receptor- $\gamma$ ), and $S C D 1$ (encoding stearoylCoA desaturase; Table 3). At the same time, there was an increase in the expression of inflammation and immune cell infiltration markers such as CD68 (encoding cluster differentiation 68), IL10 (encoding IL-10), 

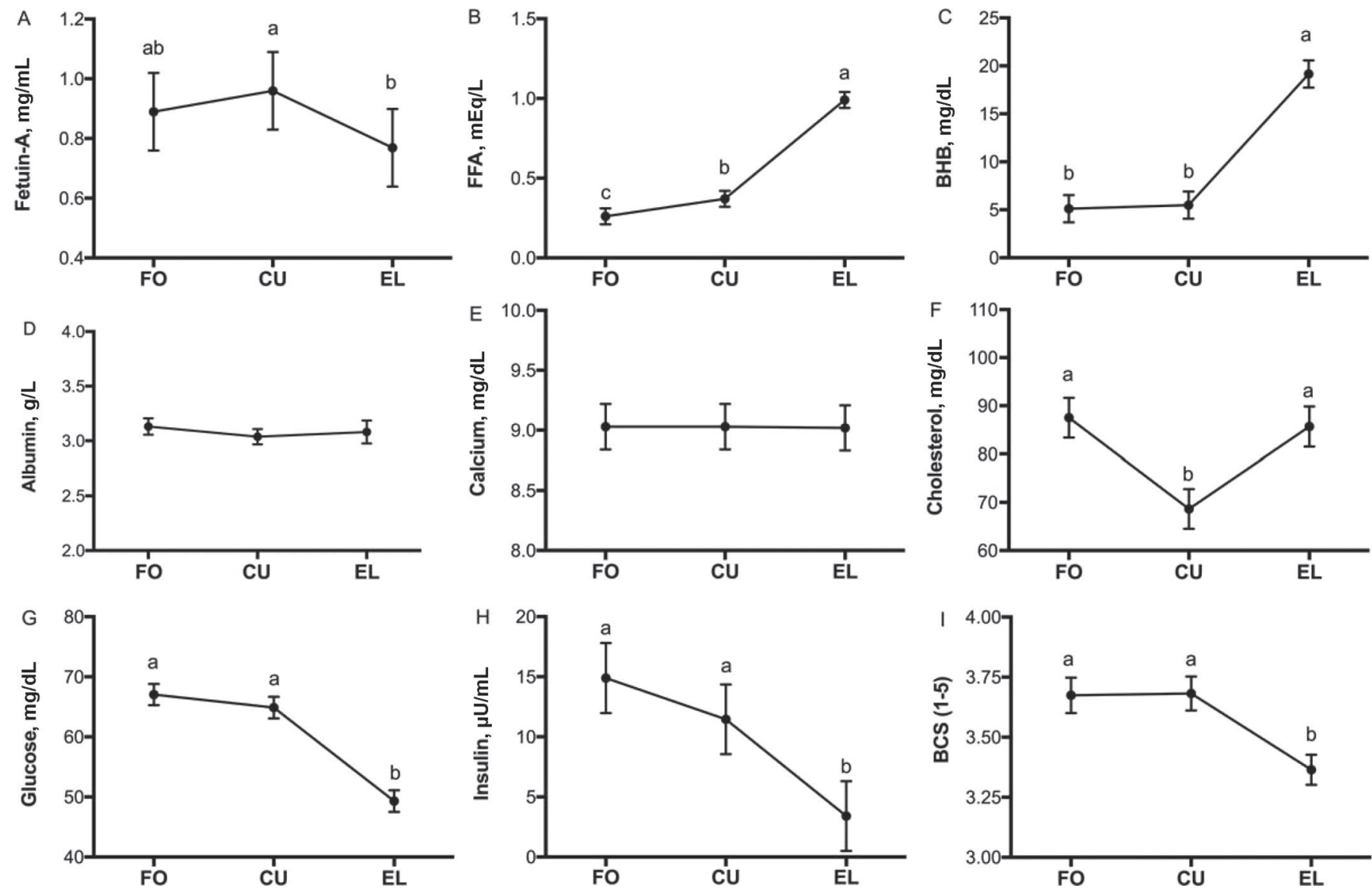

Figure 1. Serum dynamics of (A) fetuin-A, (B) free fatty acids (FFA), (C) BHB, (D) albumin, (E) calcium, (F) total cholesterol, (G) glucose, and $(\mathrm{H})$ insulin concentrations and $(\mathrm{I}) \mathrm{BCS}$ in dairy cows $(\mathrm{n}=16)$ at the far-off $(\mathrm{FO} ;-26 \pm 7 \mathrm{~d})$, close-up $(\mathrm{CU} ;-8 \pm 5 \mathrm{~d})$, and early-lactation $(\mathrm{EL} ; 10 \pm 2 \mathrm{~d})$ time points. Results represent means \pm SEM, $\mathrm{n}=16$. Bars with different letters $(\mathrm{a}-\mathrm{c})$ are significantly different $(P \leq 0.05)$.

and SPP1 (encoding osteopontin-1) at EL (Table 3). A correlation analysis demonstrated that AT AHSG transcription was negatively associated with the expression of AT SPP1 $(\mathrm{r}=-0.46 ; P=0.01)$ and $C D 68(\mathrm{r}=$ $-0.37 ; P=0.04)$ over the periparturient period. The expression of FetA protein in AT was also negatively associated with the gene expression of AT inflammatory markers such as $C D 68(\mathrm{r}=-0.38 ; P=0.04), C D 44(\mathrm{r}$ $=-0.38 ; P=0.04$ ), and $C C L 2$ (encoding monocyte chemoattractant protein-1, $\mathrm{r}=-0.38 ; P=0.04$ ).

Table 2. Pearson correlation coefficients for serum concentrations of fetuin-A, free fatty acids (FFA), BHB, total cholesterol, albumin, calcium, glucose, and insulin and BCS and BCS loss over the periparturient period in multiparous dairy cows

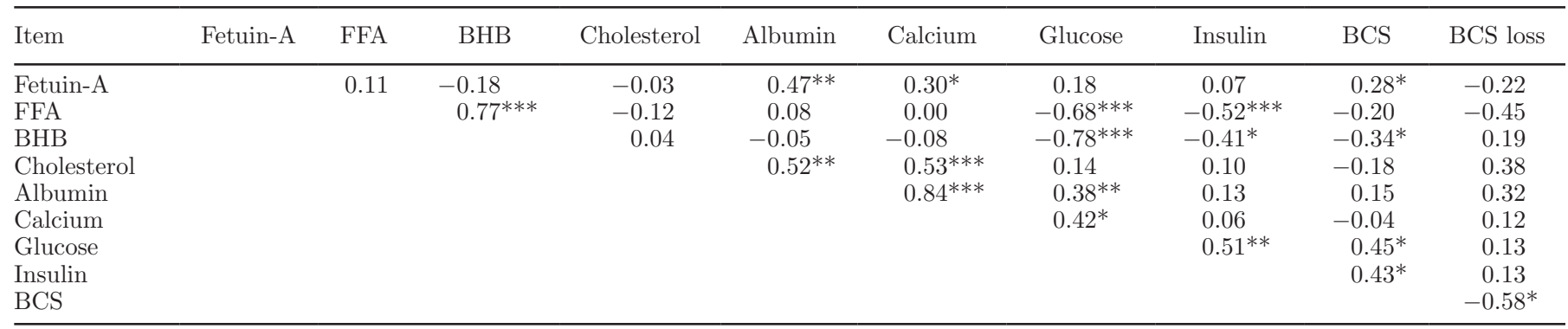

${ }^{1}$ Samples were obtained from multiparous dairy cows $(\mathrm{n}=16)$ at (days relative to calving \pm SEM) the far-off dry $(-26 \pm 7 \mathrm{~d})$, close-up dry $(-8$ $\pm 5 \mathrm{~d})$, and early-lactation $(10 \pm 2 \mathrm{~d})$ time points.

${ }^{*} P<0.05 .{ }^{* *} P<0.001$. ${ }^{* * *} P<0.0001$ 

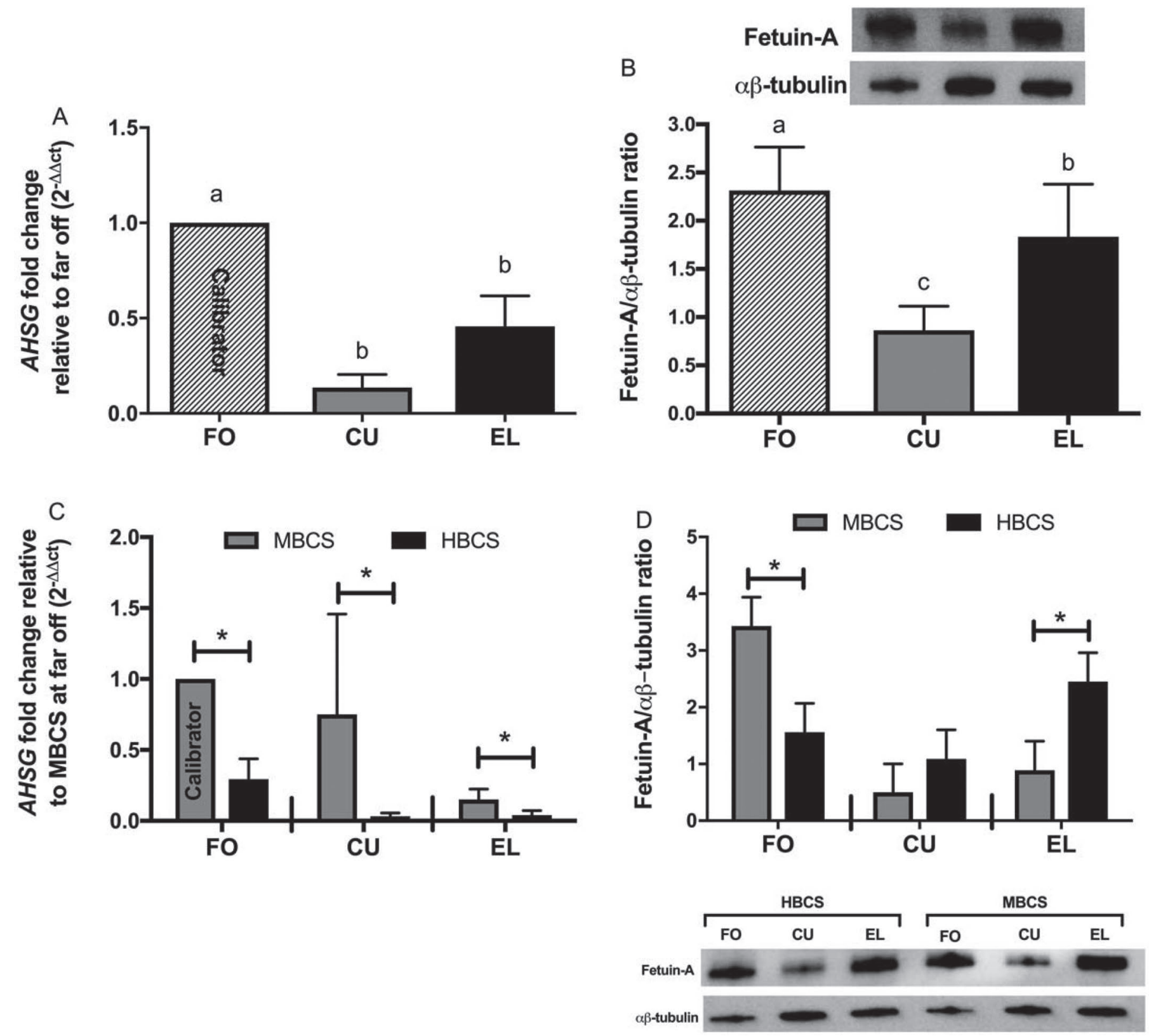

Figure 2. Adipose tissue (A) fetuin-A gene expression $(A H S G)$ and $(\mathrm{B})$ protein content in periparturient dairy cows $(\mathrm{n}=10)$ at the far-off $(\mathrm{FO} ;-26 \pm 7 \mathrm{~d}$ ), close-up (CU; $-8 \pm 5 \mathrm{~d})$, and early-lactation (EL; $10 \pm 2 \mathrm{~d}$ ) time points. Adipose tissue (C) fetuin-A gene expression and (D) protein content in high (HBCS; $\mathrm{n}=6$ ) or moderate (MBCS; $\mathrm{n}=4)$ BCS cows. For real-time quantitative PCR results, values are shown as $2^{(-\Delta \Delta \mathrm{CT})}(\mathrm{CT}=$ cycle threshold), with FO subcutaneous adipose tissue samples set as the calibrator. For Western blot analysis, $\alpha \beta$-tubulin was used as a loading control, and values are expressed as a ratio between fetuin-A and $\alpha \beta$-tubulin adjusted band intensity (mm ${ }^{2}$ ). Results represent means \pm SEM. Bars with different letters $(\mathrm{a}-\mathrm{c})$ and asterisk indicate significant differences $(P \leq 0.05)$.

\section{Prepartum BCS and FetA in Periparturient Cows}

When analyzing metabolic biomarkers by BCS groups, HBCS increased circulating FFA, glucose, and insulin concentrations compared with MBCS (Table 4). The HBCS cows lost significantly more fat mass $(-0.37 \pm$ 0.05 BCS points) compared with MBCS cows $(-0.23 \pm$
0.06 BCS points) throughout the periparturient period, yet BCS at dry-off had no effect on serum FetA concentrations over FO, CU, and EL (Table 4). However, both AT AHSG expression and FetA protein content dynamics differed between HBCS and MBCS. Adipose tissue $A H S G$ expression was lower in HBCS cows across all time points compared with MBCS cows (Figure 2C). 
FETUIN-A AND PERIPARTURIENT COW ADIPOSE FUNCTION

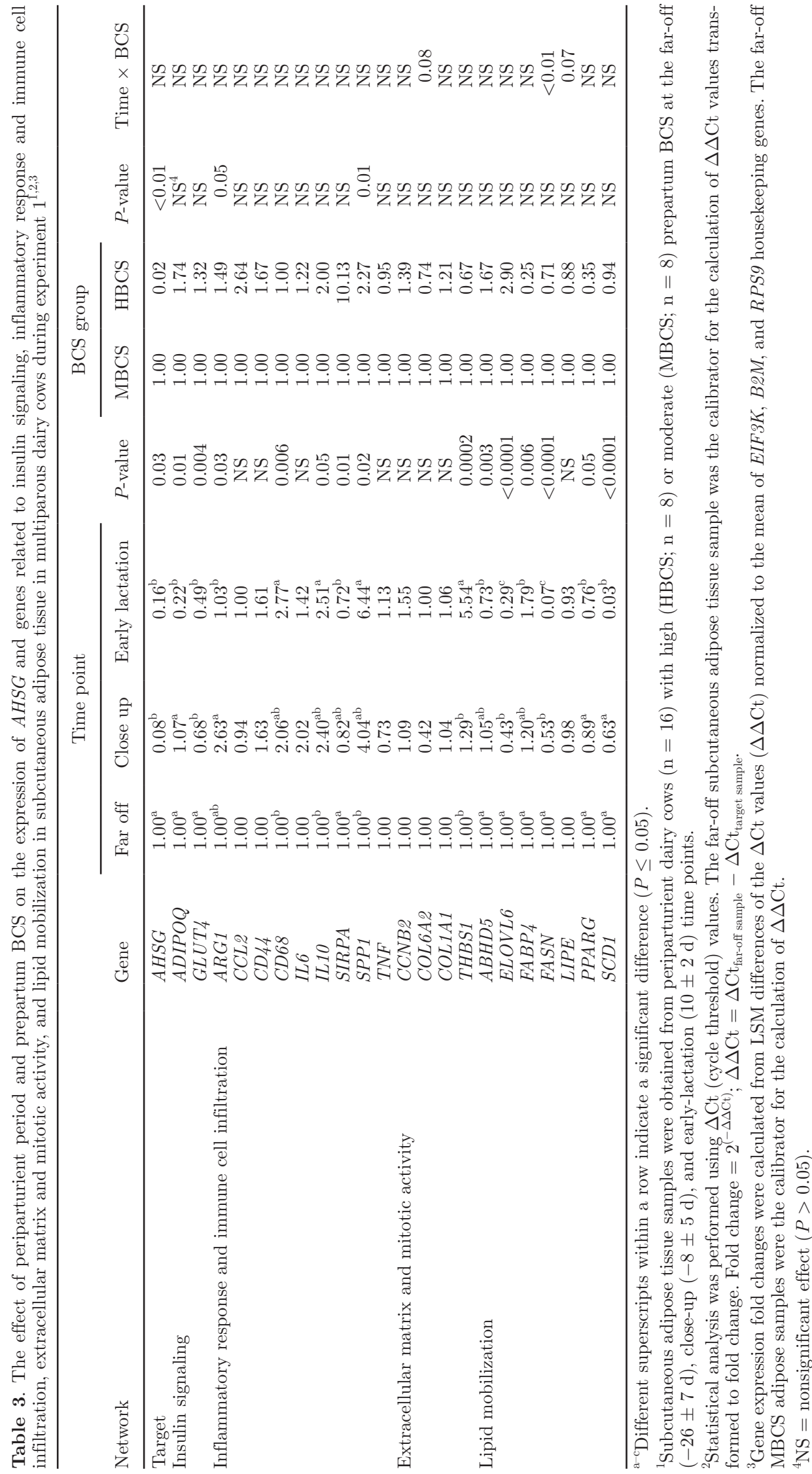

Journal of Dairy Science Vol. 101 No. 3, 2018 
When analyzing the gene expression of gene networks of inflammatory responses in AT, we found that HBCS increased expression of ARG1 (encoding arginase-1) and SPP1 across time points compared with MBCS (Table 3). There was an interaction between BCS group and time point on AT FetA protein expression. Adipose tissue FetA protein content increased in MBCS cows at FO and decreased at EL compared with HBCS cows (Figure 2D). There was no difference in AT FetA protein expression between MBCS and HBCS at CU (Figure 2D).

\section{Short-Term Feed Restriction-Induced NEB Does Not Affect the Expression of FetA}

In experiment 2, we examined serum and AT FetA gene and protein expression following a 4-d feed restriction protocol in nonpregnant mid-lactation cows. Feed restriction induced NEB in FR cows $(-14.1 \pm$ $0.62 \mathrm{Mcal} / \mathrm{d}$ of $\mathrm{NE}_{\mathrm{L}}$ ), whereas $\mathrm{AL}$ cows stayed in positive energy balance for the duration of the experiment $\left(3.2 \pm 0.66 \mathrm{Mcal} / \mathrm{d}\right.$ of $\mathrm{NE}_{\mathrm{L}}$; Contreras et al., 2016b). Feed restriction increased AT lipolysis in FR as demonstrated by increased serum FFA concentrations $(0.65$ $\pm 0.03 \mathrm{mEq} / \mathrm{L})$ compared with $\mathrm{AL}$ cows $(0.16 \pm 0.03$ $\mathrm{mEq} / \mathrm{L}$; Figure 3A; Supplemental Table S2, https:// doi.org/10.3168/jds.2017-13644) and increased AT phosphorylation of sensitive hormone lipase at serine 660 (described in Contreras et al., 2016b). Serum concentrations of FetA were not affected by the short-term lipolysis induced by feed restriction $(1.09 \pm 0.09$ vs. $1.17 \pm 0.09 \mathrm{mg} / \mathrm{mL}$ in FR and AL, respectively; Figure 3B). Adipose tissue $A H S G$ expression and FetA protein content were not influenced by feed restriction across subcutaneous and omental AT samples (Figure 3C and D).

\section{Bovine Adipocytes Express FetA}

To determine whether FetA is an adipokine in bovines as demonstrated in nonruminant species, we evaluated its gene expression and protein content in bovine adipocytes cultured in vitro. Our induction protocol was effective in inducing adipogenesis after $10 \mathrm{~d}$ of culture, as these cells expressed adipocyte signature genes such as FABP 4, FATP1, and DGAT1 and exhibited accumulation of intracellular lipids as demonstrated by AdipoRed assay and Oil Red O staining (Supplemental Figure S2, https://doi.org/10.3168/jds.2017-13644). Analysis of gene expression (Figure 4A) and Western blotting (Figure 4B) demonstrated for the first time that preadipocytes and mature bovine adipocytes express abundant $A H S G$ mRNA and FetA protein. The $A H S G$ mRNA abundance detected in cultured adipo-

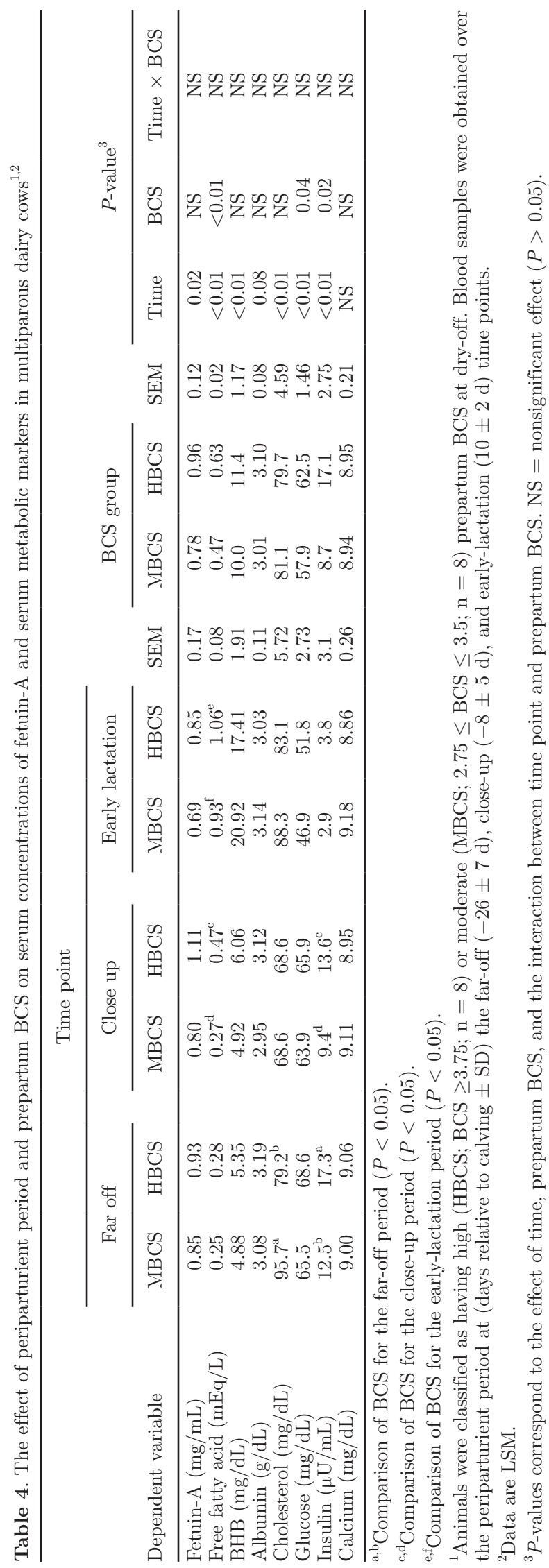



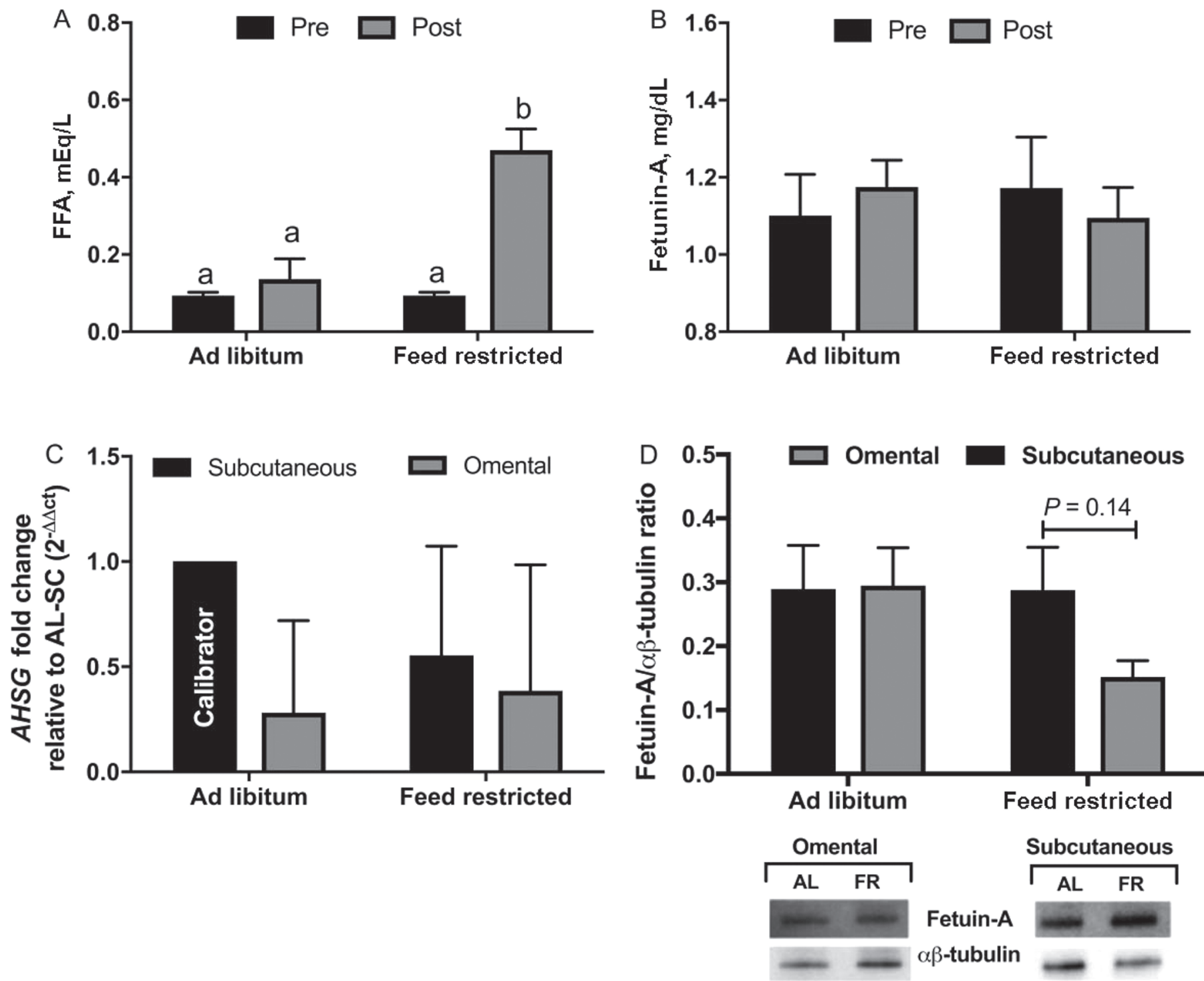

Figure 3. Serum and adipose tissue fetuin-A content in mid-lactation dairy cows $(\mathrm{n}=14)$ assigned to 1 of 2 feeding protocols: ad libitum $(\mathrm{AL} ; \mathrm{n}=7)$ or feed restricted $(\mathrm{FR} ; \mathrm{n}=7)$. Serum concentrations of $(\mathrm{A})$ free fatty acids $(\mathrm{FFA})$ and $(\mathrm{B})$ fetuin-A. Blood samples were collected at $\mathrm{d}-2$ (pre) and 4 (post) relative to the onset of feed restriction. Adipose tissue (C) fetuin-A gene expression $(A H S G)$ and (D) protein content. Subcutaneous and omental adipose tissue were collected at the final day of feed restriction. For real-time quantitative PCR results, values are shown as $2^{(-\Delta \Delta \mathrm{CT})}(\mathrm{CT}=$ cycle threshold), with ad libitum subcutaneous samples set as the calibrator. For Western blot analysis, $\alpha \beta$-tubulin was used as a loading control, and values are expressed as a ratio between fetuin-A and $\alpha \beta$-tubulin adjusted band intensity (mm ${ }^{2}$ ). Results represent means \pm SEM. Bars with different letters $(a, b)$ are significantly different $(P \leq 0.05)$.

cytes was similar to that observed in freshly isolated adipocytes and subcutaneous AT from periparturient dairy cows (data not shown).

\section{FetA and Adipocyte Inflammatory Response}

Because FetA is reported to be an APP, we evaluated the effect of an inflammatory challenge with LPS on the expression of FetA by cultured adipocytes. After $4 \mathrm{~h}$ of stimulation with LPS, adipocyte $A H S G$ expression was not affected (Figure 5A); however, FetA content in adi- pocytes was decreased (Figure 5B). Vinculin content, the loading control, was not affected by LPS treatment $(P=0.46)$. To establish the inflammatory response of adipocytes to FetA, we determined the effect of the exposure of cultured adipocytes to $0,50,100$, or 200 $\mu \mathrm{g} / \mathrm{mL}$ of FetA, or LPS as a positive inflammatory control. Bovine adipocytes treated with $50(P=0.03)$, $100(P=0.02)$, or $200(P=0.02) \mu \mathrm{g} / \mathrm{mL}$ of FetA had lower CCL2 expression compared with LPS (Figure $5 \mathrm{C})$. However, we did not observe a dose response to FetA on adipocyte $C C L 2$ gene expression $(P=0.94)$ or 
on the expression of IL6, LIPE, FABP 4, FASN, FATP1, ELOVL6, or DGAT1 after the incubation with FetA or LPS (data not shown).

\section{DISCUSSION}

Adequate concentrations of circulating FFA transporters such as FetA and albumin are required for an efficient adaptation to intense lipid mobilization during the periparturient period. Despite the high affinity of FetA as an FFA carrier in nonruminant models, it is presently unknown whether this protein is produced by
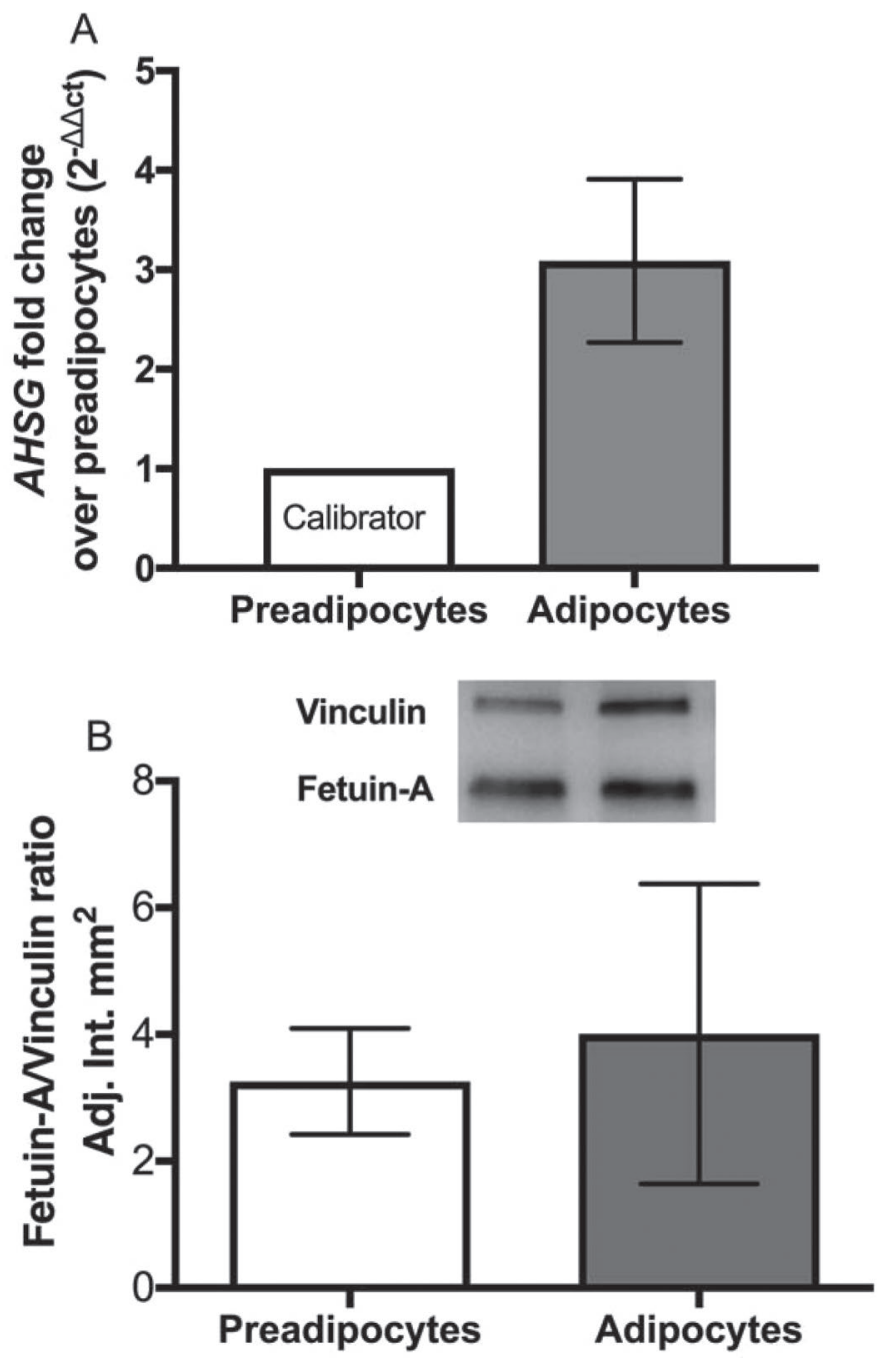

Figure 4. (A) Fetuin-A gene expression $(A H S G)$ and (B) protein content in bovine preadipocytes and differentiated adipocytes derived from tailhead subcutaneous adipose depot of dairy cows $(\mathrm{n}=$ 5). Analyses were performed on d 10 of differentiation. For real-time quantitative PCR results, values are shown as $2^{(-\Delta \Delta \mathrm{CT})}(\mathrm{CT}=$ cycle threshold), with preadipocytes set as the calibrator. For Western blot analysis, vinculin was used as a loading control, and values are expressed as a ratio between fetuin- $\mathrm{A}$ and vinculin adjusted band intensity (Adj. Int.; $\mathrm{mm}^{2}$ ). Results represent means \pm SEM.

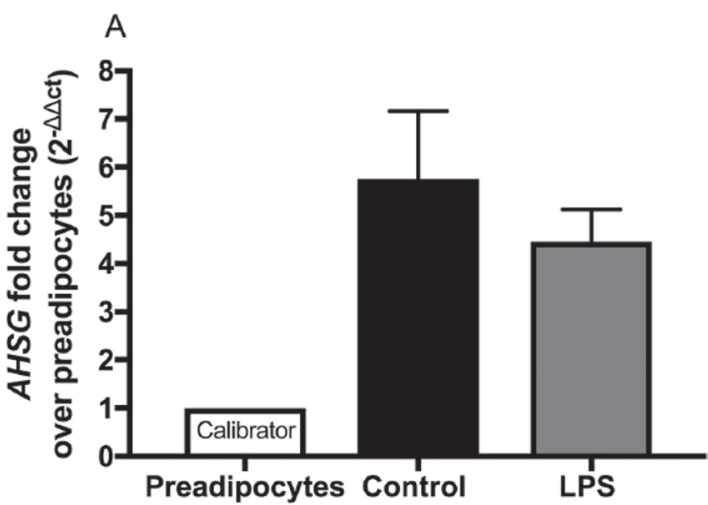

B
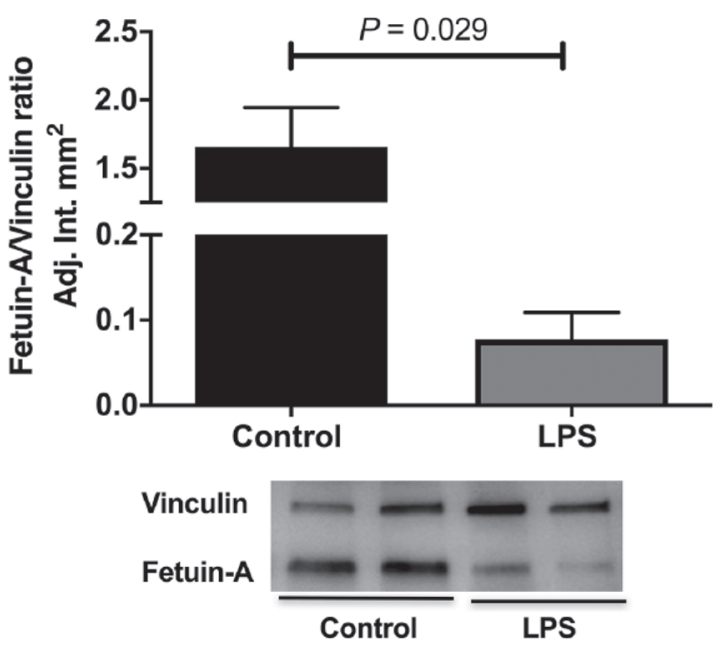

C

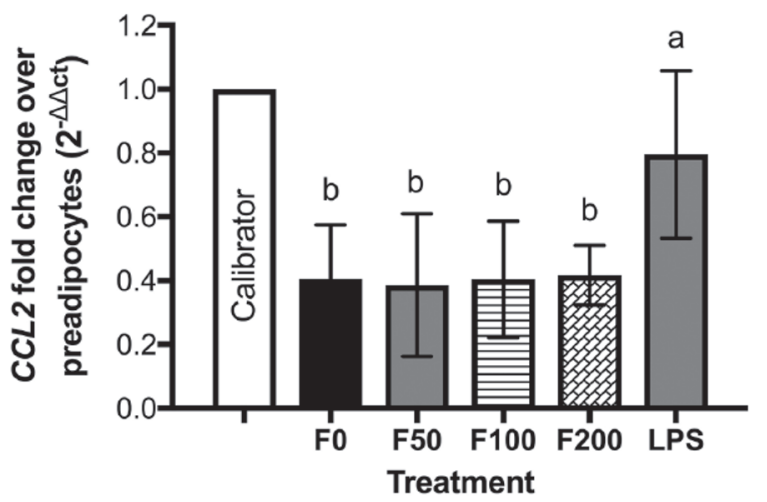

Figure 5. (A) Fetuin-A gene expression $(A H S G)$ and (B) protein content in bovine adipocytes derived from tailhead subcutaneous adipose depot of dairy cows $(\mathrm{n}=6$ per treatment $)$ treated with serum-free medium (control) or with $250 \mathrm{ng} / \mathrm{mL}$ of LPS for $4 \mathrm{~h}$. (C) Monocyte chemoattractant protein-1 (CCL2) gene expression in bovine adipocytes $(\mathrm{n}=6$ per treatment) treated with zero (F0), 50 (F50), 100 (F100), or $200(\mathrm{~F} 200) \mu \mathrm{g} / \mathrm{mL}$ of fetuin-A or $250 \mathrm{ng} / \mathrm{mL}$ of LPS for 4 $\mathrm{h}$. The experiment was performed on d 10 of differentiation. For realtime quantitative PCR results, values are shown as $2^{(-\Delta \Delta \mathrm{CT})}(\mathrm{CT}=$ cycle threshold), with preadipocytes set as the calibrator. For Western blot analysis, vinculin was used as a loading control, and values are expressed as a ratio between fetuin- $\mathrm{A}$ and vinculin adjusted band intensity (Adj. Int.; $\mathrm{mm}^{2}$ ). Results represent means \pm SEM. Bars with different letters $(\mathrm{a}, \mathrm{b})$ are significantly different $(P \leq 0.05)$. 
bovine adipocytes and the effects of lipolysis intensity, lactation stage, and BCS on its circulating concentrations and AT content. In the present study, we found that circulating and AT FetA dynamics were inversely associated with lipolysis intensity and inflammatory responses around parturition. Furthermore, changes in its systemic and AT concentration patterns corresponded to those of a negative APP. However, FetA was not affected by feed restriction-induced NEB in mid-lactation cows. These results provided initial support for a potential role of FetA as an autocrine modulator of AT response to lipolysis and inflammation to support the physiological adaptations to NEB around parturition.

\section{Circulating FetA Concentration Change over the Periparturient Period}

In our study, serum FetA concentrations decreased from the last week of gestation to the second week of lactation. These patterns follow those observed in women with gestational diabetes, where FetA concentrations increase during the last 3 mo of gestation and decrease during the postpartum period (Iyidir et al., 2015). Iyidir et al. (2015) suggested that high prepartum FetA concentration may be related to its role in the development of insulin resistance and to the metabolic changes observed during gestational diabetes, especially in those women with high body mass index. In humans, obesity increases circulating FetA concentrations (Brix et al., 2010), and these are positively associated with serum FFA concentrations (Stefan and Haring, 2013; Jialal et al., 2016). Notably, loss of fat mass induces a reduction in plasma FetA (Brix et al., 2010; Choi et al., 2013). In our study, even though HBCS cows lost more BCS from dry-off until 10 DIM compared with MBCS cows, there was no effect of prepartum adiposity or fat mass loss on serum FetA concentrations. Additionally, in contrast to humans (Stefan and Haring, 2013), there was no association between serum concentrations of FFA and FetA. Overall, our results suggest that concentrations of circulating FetA change over the periparturient period but are not affected by adiposity at dry-off or by moderate BCS loss around parturition.

\section{FetA Is Not Affected by NEB in Cows During Mid Lactation}

Using a feed restriction model in mid-lactation cows, we determined whether NEB, at an intensity similar to that observed during the periparturient period, influences FetA dynamics independent of confounding factors associated with parturition. The lipolytic surge during feed restriction did not affect FetA content in serum and AT. These results agree with a previous report in which women subjected to $3 \mathrm{~d}$ of energy restriction exhibited similar plasma FetA concentrations during both pre- and postfasting periods (Hwang et al., 2014). We speculate that FetA serum and AT contents were not affected by the feed restriction-induced NEB due to its short duration (only $4 \mathrm{~d}$ ) and due to the stage of lactation of the animals. For instance, in our studies, mid-lactation cows adapted to NEB by reducing their milk energy output $(25.7 \pm 0.67$ vs. $13.7 \pm 1.42 \mathrm{~kg} / \mathrm{d}$ in AL and FR cows, respectively; Contreras et al., 2016b), whereas periparturient cows exhibited a continuous increase in milk production from $37.4 \pm 1.0 \mathrm{~kg} / \mathrm{d}$ at 1 DIM to $44.7 \pm 1.0 \mathrm{~kg} / \mathrm{d}$ at 10 DIM. This period of increasing milk production in early-lactation cows was concurrent with an extended and intense period of lipolysis that lasted for at least $3 \mathrm{wk}$ (throughout $\mathrm{CU}$ and EL) and coincided with a significant decrease in serum FetA concentrations. Additionally, whereas feed restriction led to mild changes in the AT inflammatory response in mid-lactation cows (Contreras et al., 2016b), after parturition dairy cows increased the AT expression of inflammatory cytokines and immune cell infiltration markers (i.e., CD68, IL10, and SPP1) compared with FO. Overall, these results demonstrated that lipolysis is just one of the factors influencing serum and AT FetA concentrations in periparturient cows.

In the present study, serum FetA showed similar dynamics to concentrations of albumin and paraoxonase- 1 in periparturient cows, which are well-characterized anti-inflammatory negative APP (Bionaz et al., 2007). Similar to these APP, serum FetA concentrations decreased as parturition and the onset of lactation approached and lipolysis intensity increased. An early study demonstrated a strong association between FetA and albumin during inflammation (Lebreton et al., 1979), and this coincides with our results that show a positive association between serum FetA and circulating albumin throughout the periparturient period. Although the role of FetA as an APP is poorly characterized in ruminants, it is well documented in humans. Similar to serum albumin, low FetA concentrations are associated with malnutrition, atherosclerosis, and renal and cardiovascular diseases independent of age and body mass index (Stenvinkel et al., 2005; Metry et al., 2008; Jenkins et al., 2011).

\section{FetA Is an Adipokine and a Negative APP in Bovine Adipose}

This is the first study to report on the expression of AHSG expression and FetA protein content in primary bovine adipocytes. Agreeing with previous reports in humans and rodents (Jialal et al., 2015, 2016), we demonstrated an abundant expression of $A H S G$ and 
FetA protein content in bovine preadipocytes and differentiated adipocytes. In agreement with Zachut et al. (2017), our results also confirm that FetA is an adipokine in bovines. Additionally, our adipocyte culture model exhibited $A H S G$ transcription levels similar to those observed in subcutaneous AT in early-lactation dairy cows, demonstrating that adipocyte culture models may be an efficient in vitro system for studying the effects of FetA on AT function.

Fetuin-A is an APP regulated by different proinflammatory mediators such as TNF and IL6 (Wang and Sama, 2012; Zhang et al., 2014), which are known to be expressed and upregulated during excessive lipolysis and dysregulated inflammation in the AT of periparturient dairy cows (Contreras et al., 2015). Our in vitro data revealed a decrease in FetA protein content in adipocytes challenged with LPS and suggest that FetA is a negative APP in bovine AT. Similarly, FetA abundance in AT decreased 1.5 times during heat stress and was associated with increased proinflammatory and prooxidative status in late-pregnant dairy cows (Zachut et al., 2017). Currently, the direct effect of acute inflammation on FetA secretion by bovine AT remains poorly documented.

Fetuin-A is an anti-inflammatory mediator that is negatively affected by the release of acute inflammation-derived cytokines and may be critical for regulating innate immune response (Wang et al., 1997; Ombrellino et al., 2001; Wang and Sama, 2012). Fetuin-A participates in the deactivation of human macrophages (Wang et al., 1997) and inhibits the production of TNF, IL1, and nitric oxide during LPS-stimulated acute inflammation in a dose-dependent manner (Dziegielewska et al., 1998); this suggests that FetA is an effective antiinflammatory APP (Li et al., 2011; Wang and Sama, 2012). We observed lower expression of monocyte chemoattractant protein-1 (MCP-1; CCL2 gene) in bovine adipocytes treated with different doses of FetA compared with LPS. This indicates that FetA does not induce acute proinflammatory responses as observed with our positive control (LPS) for inflammation. Although conjecture, FetA may restrain local inflammation by modulating macrophage- and adipocyte-derived proinflammatory cytokines during periods of intense lipolysis such as the periparturient period; however, the specific mechanisms of inflammation modulation by FetA remain to be established.

\section{Adipose FetA and AT Function}

The AT expression patterns of AHSG during the periparturient period were similar to those of adipogenesis, lipogenesis, and lipid transport-related genes such as ABHD5, ELOVL6, FASN, FABP4, SCD1, and PPAR $\gamma$.
Reduced expression of these genes at EL suggests a reduced lipogenic function in subcutaneous AT when $A H S G$ expression was also the least. Besides being an FA transporter that is responsible for a large part of the FA delivery to cells (Kumbla et al., 1989), FetA was reported to augment the uptake of exogenous oleic acid and the synthesis of triacylglycerol in a human adipogenic model compared with albumin (Cayatte et al., 1990; Subbiah, 1991).

In our study, the dynamics of AT FetA differed from those in serum during the periparturient period. Serum glycoproteins, such as FetA, are products of aminosugar metabolism in the liver (Lai et al., 1981); thus, circulating FetA concentrations are more likely to reflect liver metabolism than AT. We cannot exclude the possibility that changes in liver function associated with the periparturient period, including increased hepatocyte lipid accumulation, could have affected circulating FetA concentrations; however, this was not evaluated in the present study. The differences in AT and serum dynamics of FetA in periparturient cows may also indicate that subcutaneous AT has an inherent pattern of FetA secretion that could be related to the FetA autocrine role within subcutaneous AT. However, the secretion of AT-derived FetA into systemic circulation in ruminants remains to be explored.

In the present study, we observed that AT AHSG expression and FetA protein content were negatively associated with inflammation and immune cell infiltration into AT during the periparturient period, as demonstrated by its inverse correlation with the expression of SPP1,CD44, CD68, and CCL2. The proinflammatory chemokine MCP-1 encoded by CCL2 is upregulated in AT of postpartum compared with prepartum dairy cows (Mann et al., 2016) and in early-lactation cows with displaced abomasum (Contreras et al., 2015). Complementarily to MCP-1, osteopontin (SSP1) and its receptor $C D 44$ as well as $C D 68$ also favor an influx of macrophages in AT of early-lactation dairy cows (Akter et al., 2012; Strieder-Barboza et al., 2017). These results suggest that FetA may act as a negative APP locally in AT and may have anti-inflammatory properties in AT of dairy cows, similar to its effects in different tissues and cell types in nonruminant species (reviewed by Wang and Sama, 2012).

\section{CONCLUSIONS}

Results from this study demonstrated that FetA is an adipokine and a negative APP systemically and locally in the subcutaneous AT of dairy cows. Fetuin-A decreased after parturition, coinciding with the lipolytic and proinflammatory state observed in periparturient dairy cows in early lactation. Future studies will deter- 
mine the potential of serum FetA concentrations as a disease predictor biomarker in periparturient cows and the mechanisms by which FetA may modulate AT lipid mobilization and inflammatory responses in dairy cows.

\section{ACKNOWLEDGMENTS}

This research was supported by USDA-National Institute of Food and Agriculture (Washington, DC) grant 2015-67015-23207; Department of Large Animal Clinical Sciences (East Lansing, MI); Michigan Animal Health Foundation, Research and Educational Grants Program (2015-2016); and Global Agri-Trade Corporation (Gardena, CA). The authors are grateful to Courtney L. Preseault, Laura Gualdron, Kyan Thelen, Connor Lewicki, J. Guy, M. Western, and the staff at the Michigan State University Dairy Field Laboratory (East Lansing) for animal care and technical assistance; Sarah E. Schmidt for paper editing and technical assistance; and Jeff Landgraf at the Michigan State University Genomic Research Technology Core Facility (East Lansing).

\section{REFERENCES}

Akter, S. H., S. Häussler, D. Germeroth, D. von Soosten, S. Dänicke, K. H. Südekum, and H. Sauerwein. 2012. Immunohistochemical characterization of phagocytic immune cell infiltration into different adipose tissue depots of dairy cows during early lactation. J. Dairy Sci. 95:3032-3044.

Bionaz, M., E. Trevisi, L. Calamari, F. Librandi, A. Ferrari, and G. Bertoni. 2007. Plasma paraoxonase, health, inflammatory conditions, and liver function in transition dairy cows. J. Dairy Sci. 90:1740-1750.

Brix, J. M., H. Stingl, F. Höllerl, G. H. Schernthaner, H.-P. Kopp, and G. Schernthaner. 2010. Elevated Fetuin-A concentrations in morbid obesity decrease after dramatic weight loss. J. Clin. Endocrinol. Metab. 95:4877-4881.

Cayatte, A. J., L. Kumbla, and M. T. Subbiah. 1990. Marked acceleration of exogenous fatty acid incorporation into cellular triglycerides by fetuin. J. Biol. Chem. 265:5883-5888.

Chen, H.-Y., Y.-L. Chiu, S.-P. Hsu, M.-F. Pai, C.-F. Lai, Y.-S. Peng, T.-W. Kao, K.-Y. Hung, T.-J. Tsai, and K.-D. Wu. 2009. Association of serum fetuin A with truncal obesity and dyslipidemia in non-diabetic hemodialysis patients. Eur. J. Endocrinol. 160:777783.

Choi, K. M., K. A. Han, H. J. Ahn, S. Y. Lee, S. Y. Hwang, B.-H. Kim, H. C. Hong, H. Y. Choi, S. J. Yang, H. J. Yoo, S. H. Baik, D. S. Choi, and K. W. Min. 2013. The effects of caloric restriction on Fetuin-A and cardiovascular risk factors in rats and humans: A randomized controlled trial. Clin. Endocrinol. (Oxf.) 79:356-363.

Contreras, G. A., W. Raphael, S. Mattmiller, J. Gandy, and L. Sordillo. 2012. Nonesterified fatty acids modify inflammatory response and eicosanoid biosynthesis in bovine endothelial cells. J. Dairy Sci. 95:5011-5023.

Contreras, G. A., E. Kabara, J. Brester, L. Neuder, and M. Kiupel. 2015. Macrophage infiltration in the omental and subcutaneous adipose tissues of dairy cows with displaced abomasum. J. Dairy Sci. 98:6176-6187.

Contreras, G. A., Y.-H. Lee, E. P. Mottillo, and J. G. Granneman. 2014. Inducible brown adipocytes in subcutaneous inguinal white fat: The role of continuous sympathetic stimulation. Am. J. Physiol. Endocrinol. Metab. 307:E793-E799.

Contreras, G. A., N. J. O'Boyle, T. H. Herdt, and L. M. Sordillo. 2010. Lipomobilization in periparturient dairy cows influences the composition of plasma nonesterified fatty acids and leukocyte phospholipid fatty acids. J. Dairy Sci. 93:2508-2516.

Contreras, G. A., K. Thelen, N. Ayala-Lopez, and S. W. Watts. 2016a. The distribution and adipogenic potential of perivascular adipose tissue adipocyte progenitors is dependent on sexual dimorphism and vessel location. Physiol. Rep. 4:e12993.

Contreras, G. A., K. Thelen, S. E. Schmidt, C. Strieder-Barboza, C. L. Preseault, W. Raphael, M. Kiupel, J. Caron, and A. L. Lock. 2016b. Adipose tissue remodeling in late-lactation dairy cows during feed-restriction-induced negative energy balance. J. Dairy Sci. 99:10009-10021.

Dasgupta, S., S. Bhattacharya, A. Biswas, S. S. Majumdar, S. Mukhopadhyay, and S. Ray. 2010. NF-kappaB mediates lipid-induced fetuin-A expression in hepatocytes that impairs adipocyte function effecting insulin resistance. Biochem. J. 429:451-462.

Daveau, M., D. Christian, N. Julen, M. Hiron, P. Amaud, and J.P. Lebreton. 1988. The synthesis of human $\alpha-2$-HS glycoprotein is down-regulated by cytokines in hepatoma HepG2 cells. FEBS Lett. 241:191-194.

Dziegielewska, K. M., N. A. Andersen, and N. R. Saunders. 1998. Modification of macrophage response to lipopolysaccharide by fetuin. Immunol. Lett. 60:31-35.

Edmonson, A. J., I. J. Lean, L. D. Weaver, T. Farver, and G. Webster. 1989. A body condition scoring chart for Holstein dairy cows. J. Dairy Sci. 72:68-78.

Heinrichsdorff, J., and J. M. Olefsky. 2012. Fetuin-A: The missing link in lipid-induced inflammation. Nat. Med. 18:1182-1183.

Hwang, J. J., B. Thakkar, J. P. Chamberland, and C. S. Mantzoros. 2014. Circulating fetuin-A levels are not affected by short and long-term energy deprivation and/or by leptin administration. Metabolism 63:754-759.

Ix, J. H., and K. Sharma. 2010. Mechanisms linking obesity, chronic kidney disease, and fatty liver disease: The roles of fetuin-A, adiponectin, and AMPK. J. Am. Soc. Nephrol. 21:406-412.

Iyidir, O. T., C. Degertekin, B. Yilmaz, A. Altinova, F. Toruner, N. Bozkurt, G. Ayvaz, and M. Akturk. 2015. Serum levels of fetuin A are increased in women with gestational diabetes mellitus. Arch. Gynecol. Obstet. 291:933-937.

Jenkins, N. T., J. A. McKenzie, J. M. Hagberg, and S. Witkowski. 2011. Plasma fetuin-A concentrations in young and older high- and low-active men. Metabolism 60:265-271.

Jialal, I., S. Devaraj, and B. Adams-Huet. 2016. Plasma fetuin-A does not correlate with monocyte TLR4 in humans. Diabetologia $59: 222-223$.

Jialal, I., S. Devaraj, A. Bettaieb, F. Haj, and B. Adams-Huet. 2015. Increased adipose tissue secretion of Fetuin-A, lipopolysaccharidebinding protein and high-mobility group box protein 1 in metabolic syndrome. Atherosclerosis 241:130-137.

Kabara, E., L. M. Sordillo, S. Holcombe, and G. A. Contreras. 2014. Adiponectin links adipose tissue function and monocyte inflammatory responses during bovine metabolic stress. Comp. Immunol. Microbiol. Infect. Dis. 37:49-58.

Kumbla, L., A. Cayatte, and M. Subbiah. 1989. Association of a lipoprotein-like particle with bovine fetuin. FASEB J. 3:2075-2080.

Lai, P. C., L. Huang, D. Panrucker, R. Church, and F. Lorscheider. 1981. Distribution of bovine fetuin and albumin in plasma, allantoic and amniotic fluids during development. J. Reprod. Fertil. 63:53-60.

Lebreton, J. P., F. Joisel, J. P. Raoult, B. Lannuzel, J. P. Rogez, and G. Humbert. 1979. Serum concentration of human alpha 2 HS glycoprotein during the inflammatory process: Evidence that alpha 2 HS glycoprotein is a negative acute-phase reactant. J. Clin. Invest. 64:1118-1129.

Li, W., S. Zhu, J. Li, Y. Huang, Z. Rongrong, X. Fan, H. Yang, X. Gong, N. T. Eissa, W. Jahnen-Dechent, P. Wang, K. J. Tracey, A. E. Sama, and H. Wang. 2011. A hepatic protein, fetuin-A, oc- 
cupies a protective role in lethal systemic inflammation. PLoS One 6:e16945.

Mann, S., D. V. Nydam, A. Abuelo, F. A. Leal Yepes, T. R. Overton, and J. J. Wakshlag. 2016. Insulin signaling, inflammation, and lipolysis in subcutaneous adipose tissue of transition dairy cows either overfed energy during the prepartum period or fed a controlled-energy diet. J. Dairy Sci. 99:6737-6752.

Metry, G., P. Stenvinkel, A. R. Qureshi, J. J. Carrero, M. I. Yilmaz, P. Bárány, S. Snaedal, O. Heimbürger, B. Lindholm, and M. E. Suliman. 2008. Low serum fetuin-A concentration predicts poor outcome only in the presence of inflammation in prevalent haemodialysis patients. Eur. J. Clin. Invest. 38:804-811.

Ombrellino, M., H. Wang, H. Yang, M. Zhang, J. Vishnubhakat, A. Frazier, L. Scher, S. Friedman, and K. Tracey. 2001. Fetuin, a negative acute phase protein, attenuates TNF synthesis and the innate inflammatory response to carrageenan. Shock 15:181-185.

Pal, D., S. Dasgupta, R. Kundu, S. Maitra, G. Das, S. Mukhopadhyay, S. Ray, S. S. Majumdar, and S. Bhattacharya. 2012. Fetuin-A acts as an endogenous ligand of TLR4 to promote lipid-induced insulin resistance. Nat. Med. 18:1279-1285.

Pérez-Sotelo, D., A. Roca-Rivada, M. Larrosa-García, C. Castelao, I. Baamonde, J. Baltar, A. B. Crujeiras, L. M. Seoane, F. F. Casanueva, and M. Pardo. 2017. Visceral and subcutaneous adipose tissue express and secrete functional alpha2hsglycoprotein (fetuin a) especially in obesity. Endocrine 55:435-446.

Saremi, B., S. Winand, P. Friedrichs, A. Kinoshita, J. Rehage, S. Danicke, S. Haussler, G. Breves, M. Mielenz, and H. Sauerwein. 2014. Longitudinal profiling of the tissue-specific expression of genes related with insulin sensitivity in dairy cows during lactation focusing on different fat depots. PLoS One 9:e86211.

Stefan, N., A. Fritsche, C. Weikert, H. Boeing, H.-G. Joost, H.-U. Häring, and M. B. Schulze. 2008. Plasma fetuin-A levels and the risk of type 2 diabetes. Diabetes 57:2762-2767.

Stefan, N., and H.-U. Haring. 2013. Circulating fetuin-A and free fatty acids interact to predict insulin resistance in humans. Nat. Med. 19:394-395.
Steibel, J. P., R. Poletto, P. M. Coussens, and G. J. M. Rosa. 2009. A powerful and flexible linear mixed model framework for the analysis of relative quantification RT-PCR data. Genomics 94:146-152.

Stenvinkel, P., K. Wang, A. R. Qureshi, J. Axelsson, R. Pecoits-Filho, P. Gao, P. Barany, B. Lindholm, T. Jogestrand, O. Heimberger, C. Holmes, M. Schalling, and L. Nordfors. 2005. Low fetuin-A levels are associated with cardiovascular death: Impact of variations in the gene encoding fetuin. Kidney Int. 67:2383-2392.

Strieder-Barboza, C., J. de Souza, A. L. Lock, and G. A. Contreras. 2017. Effect of prepartum adiposity and lipolysis on gestational and postnatal adipose tissue inflammation and immune cell infiltration. FASEB J. 31(Suppl. 1):964.1.

Subbiah, M. T. 1991. Newly recognized lipid carrier proteins in fetal life. Proc. Soc. Exp. Biol. Med. 198:495-499.

Wang, H., and A. E. Sama. 2012. Anti-inflammatory role of fetuin-A in injury and infection. Curr. Mol. Med. 12:625-633.

Wang, H., M. Zhang, K. Soda, A. Sama, and K. J. Tracey. 1997. Fetuin protects the fetus from TNF. Lancet 350:861-862.

Wathes, D. C., Z. Cheng, M. A. Fenwick, R. Fitzpatrick, and J. Patton. 2011. Influence of energy balance on the somatotrophic axis and matrix metalloproteinase expression in the endometrium of the postpartum dairy cow. Reproduction 141:269-281.

Zachut, M., G. Kra, L. Livshitz, Y. Portnick, S. Yakoby, G. Friedlander, and Y. Levin. 2017. Seasonal heat stress affects adipose tissue proteome toward enrichment of the Nrf2-mediated oxidative stress response in late-pregnant dairy cows. J. Proteomics 158:52-61.

Zaitsu, H., and G. Serrero. 1990. Pedersen fetuin contains three adipogenic factors with distinct biochemical characteristics. J. Cell. Physiol. 144:485-491.

Zhang, P., H. Shen, J. Huang, H. Wang, B. Zhang, R. Zhou, B. Zhong, and X. Fan. 2014. Intraperitoneal administration of fetuin-A attenuates D-galactosamine/lipopolysaccharide-induced liver failure in mouse. Dig. Dis. Sci. 59:1789-1797. 